RESEARCH ARTICLE

\title{
POLITICS OF LAW ON SCHOOL DAYS POLICY: LEGAL REFORM ON INDONESIAN EDUCATION POLICY
}

\author{
Maria Dita Kristiana ${ }^{1 凶}$ \\ IPangudi Luhur Foundation, Semarang, Indonesia \\ 凶dita_maria@gmail.com
}

\section{HOW TO CITE}

Kristiana, M.D. (2020). Politics of Law on School Days Policy: Legal Reform on Indonesian Education Policy. Journal of Law and Legal Reform, 1(1), 5-24. DOI: https://doi.org/10.15294/jlll.vlil.35405.

\section{ABSTRACT}

The research is aimed to identify, analyze, and examine concerning to: (1) what is Permendikbud Law No. 23 of 2017 on the political politics of School Days? And (2) how is the implementation of Permendikbud Number 23 of 2017 concerning School Days in Semarang City? The method of this research is qualitative with the type of sociological juridical legal research. The research explored some information through interviews and observation in some schools in Semarang as well as Education Unit in Semarang Government. The research highlighted that the law politics of School Day in Semarang City included the substance of Permendikbud Number 23 of 2017, namely the strengthening of character education at the high school level, provisions on school days and hours, and implementation of school day provisions. The philosophical reasons for five days of schooling are come up from Pancasila values and the opening of the 1945 Constitution to strengthen character or character as the spirit of the national spirit. Juridical purposes for the five-day school policy are sourced from laws and regulations that every child has the right to education, the provision of learning that is democratic and fair and non-discriminatory, as well as the fulfillment of the obligation to total teaching hours for teachers as employees of the state civil apparatus. The research concluded that the implementation of Minister of Education and Culture Regulation No. 23 of 2017 concerning School Days by State High Schools in the City of Semarang is supported by four aspects of communication, disposition, human resources, and bureaucracy.

Keywords: Implementation; Organizing Education; Political Law; School Days 


\section{TABLE OF CONTENTS}

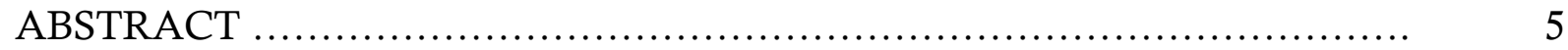

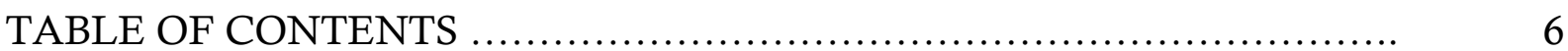

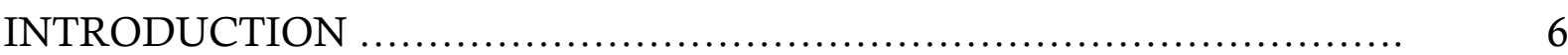

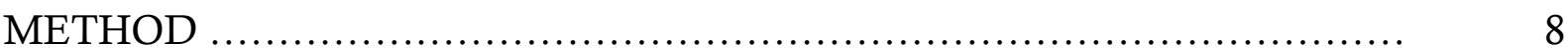

POLITICS OF LAW OF SCHOOL DAYS POLICY IN INDONESIA ........... 9

I. POLITICAL LAW CONCERNING SCHOOL DAYS IN THE

MINISTER OF EDUCATION AND CULTURE REGULATION

NUMBER 23 OF 2017 CONCERNING SCHOOL DAYS ................. 9

A. The Substance of the Regulation of the Minister of Education and

Culture No. 23 of 2017 concerning School Days ......................... 9

B. Philosophical Reasons for the Five-Day School Policy ................... 11

C. Sociological Reasons for the Five-Day School Policy .................... 12

D. Juridical Reasons for the Five-Day School Policy ........................ 13

II. IMPLEMENTATION OF PERMENDIKBUD NUMBER 23 OF 2017 CONCERNING SCHOOL DAYS IN SEMARANG CITY ................. 16

A. Communication ................................................. 16

B. Disposition ........................................................ 17

C. Human Resources ................................................... 18

D. Bureaucracy ................................................... 19

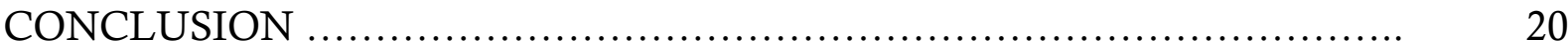

REFERENCES ............................................................ 21

\section{INTRODUCTION}

The current school curriculum, which is the 2013 curriculum, is oriented towards character education because it is not only about theory but also requires real action on character education. This illustrates that various parties pay attention to character education. This encourages the need for best practice (real best practice) in character education as an educational innovation in addition to internalizing character values. The best practice is a learning activity by learning by doing. Students must apply a positive lifestyle significantly, especially in schools through the implementation of a full-day school or five-day school (Sari, 2017).

The five-day school (FDS) is a school program where the learning process is carried out throughout the day at school. With a policy like this, more time and activity for children is spent in the school environment than outside the school. Children can be at home again after the late afternoon. The FDS program is implemented through an integrated curriculum and integrated activity approach. The development of this program can be done through curriculum development and 
management of teaching and learning activities by teachers and managers of the foundations/institutions concerned (Hidayah, 2017: 9).

Determination of the FDS policy through the issuance of the Minister of Education and Culture Regulation No. 23 of 2017 concerning School Day will ultimately lead to pros and cons in educational institutions and the community. The emergence of pros and cons followed by a variety of responses for those who pro argued to improve the quality of education, while the cons thought that the presence of FDS would erode religious non-formal education such as TPQ. The response arises because there is school compaction from six days to 5 days with the consequence of students returning home from school to evening, children are tired, and unable to attend non-formal education in the community accurately (Apriyani, 2018: 533).

The polemic that emerged after the issuance of Permendikbud continued to appear because the community considered the five-day school policy to be ineffective in the learning process of students, even though this five-day work policy was not a requirement for every school. This polemic occurred because it classified as ambiguous and the lack of socialization regarding Permendikbud No. 23 of 2017 to schools, especially parents of students, then the wrong perception emerged by the community. The objective of the Ministry of Education and Culture is educators whose intent and purpose is to equip educators to be more mature in providing subject matter for students, and this 5-day school policy is expected to be used by education staff to carry out their duties and functions optimally according to their responsibilities and tasks.

Concerns about the FDS policy continue to fill public education spaces in the country. This fact is evident from the many responses to the rejection of the FDS policy. Functional responses in the form of oral, written, and organizational communication, because FDS is seen as an idea that will hit an education climate that has been arranged long ago, however, educational institutions in the government roof unit will have structural, emotional ties although it will feel heavy to accept, but in the end the movement of educational activities in an institution will be disrupted (Rahem, 2017: 2).

The FDS policy eventually became optional for each education unit as stipulated by President Joko Widodo in Presidential Regulation Number 87 the Year 2017 concerning Strengthening Character Education to replace the Minister of Education and Culture Regulation Number 23 the Year 2017 concerning School Days. In the Perpres, there are no rules that require schools up to 8 hours a day or schools can choose to implement five days or six days a week. The Central Java Provincial Government long before the enactment of the Minister of Education and Culture Regulation No. 23 of 2017 concerning School Days has imposed a five-day school program starting in the 2015/2016 school year. This policy is a follow-up to the Circular Letter (SE) of the Governor of Central Java Number 420/006752/2015 concerning the Implementation of Education in the Education Unit in Central Java, especially at the high school and vocational level. Then followed up with the Decree of the Head of the Education Office of Central Java Province Number: 420/03737 about Supplementation Guidelines for Preparation of the Education Calendar 5 (Five) Days of Learning Per-Week of the 2015/2016 Academic Year. 
Sociological problems with FDS policy are in the form of lack of public awareness, lack of compliance, and acceptance, or rejection. The condition of the people who do not approve of the existence of a five-day school policy lacks awareness of the importance of implementing a five day school that can prevent students from negative relationships in the environment outside the school. The rejection of the policy is also a form of community non-compliance with the policies or regulations that have been set by the central government. The pros and cons of a five-day school in the community are still rolling. But amid the pros and cons, many regions have implemented the system, one of them is Central Java Province. Head of the Central Java Provincial Education Office (Central Java), Nur Hadi Amiyanto, revealed that to date, there had been 525 schools in Central Java that have implemented five-day schools. The implementation of the five-day school itself is optional, so it does not force schools that are not yet ready to implement the five-day school system (https://news.okezone.com).

From a juridical perspective, the FDS provisions, although optional, are regulated in Minister of Education and Culture Regulation Number 23 of 2017 concerning School Days and Presidential Regulation Number 87 of 2017 concerning Strengthening of Character Education has the potential to crash the Law on the National Education System (Sisdiknas), especially Chapter III Article 4 Principles for Providing Education, Chapter VI Article 13 concerning Levels and Types of Education and Article 30 concerning religious education. The existence of informal learning and religious education, which includes pesantren and madrasa diniyyah is a constitutional guarantee that its existence is recognized and the principle that the implementation of education nationally must complement each other as a whole and must not be clashed with each other.

Based on the phenomenon of the five-day school policy, which is still a pro and con in the community but is even applied to high schools in the city of Semarang, this research is essential to do. The five-day school policy through the provisions of the Minister of Education and Culture Regulation No. 23 of 2017 concerning School Days needs to be reviewed in substance and its implementation in high schools in Semarang City. Based on the background description above, the formulation of the proposed problem is (1) What is Permendikbud's legal politics Number 23 of 2017 concerning School Days ?; and (2) How is the implementation of Permendikbud Number 23 of 2017 concerning School Days in Semarang City?

\section{METHOD}

This study uses a qualitative approach as according to Ashshofa (2013: 21) that qualitative research is "Research that focuses on the general principles underlying the manifestation of symptom units in human life or patterns that are analyzed by social phenomena. Culture by using the culture of the community concerned to obtain a picture of the prevailing trends ". This type of research is sociological juridical which relies on primary data (results from the study in the field) and secondary data. 
This research was conducted in the city of Semarang, primarily in-state high schools that have implemented a five-day school policy. The reason the researchers chose the location of research in Semarang City are (1) Semarang City as one of the cities in Central Java Province that responds positively to implementing a five day school policy; (2) there are rules supporting five day school policies in the city of Semarang through the Circular of the Governor of Central Java; and (3) Semarang City with a large number of high schools used as a trial run for the application of Permendikbud Number 23 of 2017 concerning School Days. This research was conducted in four state high schools in Semarang, namely 14 Semarang High Schools, Semarang 5 High Schools, Semarang 6 High Schools, and Semarang 11 High Schools. The selection of the four schools is for practical reasons that each school represents schools from the North Semarang, West Semarang, South Semarang, and Central Semarang regions. Besides, the city of Semarang is strategically a parameter of the quality of secondary education in Central Java.

Sources of research data are primary and secondary data sources. Primary data sources in this study were obtained through interviews and observations. Secondary data can be obtained from primary, secondary, and tertiary legal materials-data collection techniques using interviews, observation, and documentation. Direct interviews were conducted with School Principals, Vice Principal of Curriculum Affairs, Teachers, and State High School students in Semarang City who implemented a five-day school policy.

This study uses data validity in the form of triangulation. According to Sugiyono (2015: 330) that triangulation is a data collection technique that combines various existing data collection techniques and data sources. Source triangulation techniques in this study are used by comparing the circumstances and perspectives of a person with multiple opinions and views of people, or in other words, and research information will be compared with several informants. Engineering triangulation means that researchers use different data collection techniques to get data from the same data source.

Data analysis in this research is qualitative data analysis. According to Moleong (2010: 248) that qualitative data analysis is an effort made by working with data, organizing data, sorting it into manageable units, synthesizing it, searching and finding patterns, finding what is essential and what is learned and deciding what can be told to others. Qualitative analysis with an interactive model consists of four stages of the cycle namely data collection, data reduction, data presentation, and concluding. 


\section{POLITICS OF LAW ON SCHOOL DAY POLICY IN INDONESIA}

\section{POLITICAL LAW ABOUT SCHOOL DAYS IN THE MINISTER OF EDUCATION AND CULTURE REGULATION NUMBER 23 OF 2017 CONCERNING SCHOOL DAYS}

A. The Substance of the Regulation of the Minister of Education and Culture No. 23 of 2017 concerning School Days

The substance of the Regulation of the Minister of Education and Culture No. 23 of 2017 is the rule regarding the provisions of school days and school hours. Article 2 of the Regulation of the Minister of Education and Culture No. 23 of 2017 can be explained that the number of days and hours used by teachers, education staff, and students in organizing education in schools is 8 (eight) hours in 1 (one) day or 40 (forty) hours for 5 (five) days in 1 (one) week. This means that the school day at the high school level (high school) since this regulation is set to change from 6 days to 5 days or in other words, school activities for two days off Saturday and Sunday.

The provisions of Article 2 paragraph (3) and (4) regulate the addition of rest periods to be limited to a maximum of 0.5 hours in 1 day or 2.5 (two points five) hours for 5 (five) days in 1 (one) week. Calculation of rest hours is not included in the calculation of 8 hours in 1 day. For example, if a high school enters starting at 07.00 the minimum return hour is 15.00. Meanwhile, if a high school wants to add a break of 0.5 hours per day, it means that students attend schooling activities for at least 8.5 hours so that students enter school at 07.00 and go home at 15.30. Thus, students spend almost a full day of learning in the school environment.

Provisions regarding school days and school hours in Permendikbud Regulation No. 23 of 2017 have benefits for teachers, as mentioned in Article 3. Article 3 can be seen that the provisions of school days and hours provide essential benefits for teachers. The first benefit for the teacher is that the teacher can carry out his workload, and the second is to carry out additional tasks attached to the implementation of the main activities under the workload of the teacher. The five-day stipulations (Monday to Friday) with total hours of teacher workload of 40 hours in 1 week do not change the substance of the teacher workload in the previous policy. However, in this policy, teachers get benefits including: (l) having more time and activities to meet the workload of teachers in schools or madrasas, without having to look for additional hours in other schools/madrasah; (2) have more time to set an example for students, foster, train, supervise and assess student development; (3) has a system and regulation that ensures supervision of various activities of students in religious institutions and other educational institutions outside of school so that it is in line with efforts to achieve educational goals in schools and madrasas and or nationally. 
Article 4 Permendikbud Number 23 of 2017 states that "School Day is used by Education Personnel to carry out their duties and functions." Then Article 5 (1) of the Minister of Education and Culture Regulation No. 23 of 2017 states that "School Days are used for students to carry out intra-curricular, co-curricular and extracurricular activities."

The Ministry of Education and Culture consistently asserted that LHS is not an FDS. The school day they are arranged in Permendikbud aims to strengthen the character education of students through intra-curricular activities, curricular activities, and extracurricular activities. There are various learning activities carried out with the guidance and guidance of the teacher. These activities are carried out while still referring to the five priority values of character education, namely religious, nationalist, cooperation, independence, and integrity. Intra-curricular activities are activities carried out to fulfill the curriculum, namely learning according to the subjects listed in the curriculum of each level of education. Co-curricular activities are activities carried out to strengthen or deepen essential competencies or indicators in subjects/fields under the curriculum. An example of a curricular activity is a visit to a museum or other place of education.

Article 7 Permendikbud Number 23 of 2017 shows that Permendikbud Number 23 of 2017 concerning School Days does not apply to kindergarten/TKLB/RA students or equivalent in religious schools and schools with special needs. This five-day school policy was decided only for schools that were ready and had implemented the 2013 Curriculum correctly. The party who assesses the readiness of schools is the head of the education office, both at the provincial and district/city levels, who are considered to best understand the performance of the education unit in their environment. The assessment includes the assessment of resources, transportation access, facilities, and infrastructure.

The implementation of school day provisions based on Permendikbud Number 23 of 2017 is regulated in Article 9 and Article 10. As mentioned in Article 8, the stipulation of School Days with a five day school system begins in 2017/2018, but for schools that are not ready to implement it step by step as regulated in Article 9 explains that the implementation of the 5 day school day policy starts in stages starting from the 2017/2018 school year, especially for schools that already have aspects of school resources and transportation aspects. Meanwhile, for schools and madrasas that have not, the government and the community that organizes educational institutions must immediately fulfill the completeness of the elements of school resources and transportation aspects.

Article 10 Regulation of the Minister of Education and Culture No. 23 of 2017 paragraph (1) states that teachers at schools who have not been able to implement the provisions of 5 School Days continue to implement the requirements of 40 (forty) hours in 1 (one) week to meet the workload of teachers. While students in schools that have not been able to implement the provisions of the School Day still implement the provisions of school hours following the learning burden on the curriculum and can carry out curricular and extracurricular activities. 


\section{B. Philosophical Reasons for the Five-Day School Policy}

The philosophical foundation of the five-day school policy through the issuance of Permendikbud Number 23 of 2017 is sourced from Pancasila. The foundation of Pancasila philosophy implies that the national education system places students as creatures created by God with all their natures (fitrah) with the task of leading the development of life with dignity and dignity, as creatures capable of becoming moral, virtuous, and noble human beings. Therefore, education is an effort to empower students to develop into full human beings, namely those who uphold and uphold the norms that apply in society and the country. For the Indonesian people, their view of life is Pancasila.

Pancasila as a philosophical basis for education, especially in the five-day school policy means that (1) in formulating education must be imbued and based on Pancasila; (2) the national education system must be based on Pancasila; and (3) human nature must be realized through education, so as to create an Indonesian human being aspired to Pancasila.

Permendikbud Number 23 of 2017 concerning School Days is issued to achieve national education goals. One of the goals of national education based on Pancasila is to increase devotion to God Almighty, intelligence, skills, and form a noble personality and strengthen the spirit of nationalism and love for the motherland. The aim is to develop the potential of students to become human beings who have faith, devoted to God Almighty, have good character, be healthy, knowledgeable, capable, creative, independent, and become democratic and responsible citizens. The education system is said to be of high quality if the learning process is exciting and challenging, so students can learn as much as possible through the experience of these activities, which can stimulate the curiosity of students to ask questions in response to wanting to know new things.

Permendikbud Number 23 of 2017 is issued with the following considerations: (a) that to prepare students to face the challenges of the development of the globalization era, it is necessary to strengthen the character of students through the restoration of character education in schools; and (b) that for the recovery of character education for students in schools to be more effective, it is necessary to optimize the role of the school. In this case, the government strengthens the character of students through the role of the school so that a five-day school policy is established so that the school can play a significant role in shaping and strengthening student character.

Strengthening the character that is based on Pancasila is more oriented towards two problems, namely in the macro development, it is more focused on fulfilling physical infrastructure and infrastructure that aims to accommodate the growing number of students. Micro, marked by the low quality of the management and implementation process in education units, with an academic-oriented school curriculum in each subject. Both of these problems show that the development of education has so far disoriented quality and excellence. Schools began to change functions, which are actually as a means for civilization and empowerment, instead of becoming more machines for printing knowledge for students even though the most 
fundamental essence of the educational mission is in the formation of character and strengthening the capacity of students as lifelong learners.

\section{Sociological Reasons for the Five-Day School Policy}

Five-Day School Policy is a program in the school system where teaching and learning activities take place for five days a week. With a policy like this, the students' busy time in a day is spent in school. Learners are back at home when it is late afternoon. This policy, which was trialed in Central Java at the beginning of the 2015/2016 school year, was the idea of Central Java Governor Ganjar Pranowo that was launched for secondary education (SMA / SMK). The reason the trial implementation of the Five Day School policy on secondary education only applies to SMA and SMK is that the Provincial Government's authority is only at SMA and SMK. Whereas for MA and MAK secondary school, the body lies with the Ministry of Religion.

The emergence of a five-day school education system in Indonesia began with the proliferation of the excellent term schools around the 1990s, which were primarily pioneered by private schools including schools labeled as Islamic. In an ideal sense, superior schools are schools that focus on the quality of the learning process, not on the quality of student input. The quality of the learning process depends on the learning system, but the fact is that excellent schools are usually characterized by high costs, complete and luxurious facilities, elite, and "professional" teaching staff. This phenomenon was then developed by managers in schools and schools into more diverse forms and became trademarks, including five-day schools and integrated schools.

Five days of school or five days school was initially conceived because of the interest of parents to get their children into five day school because of a number of factors, namely because of the increasing number of mothers working outside the home and the rising influence of television and the mobility of parents, and progress and modernity that began to develop in all aspects of life. The five-day school policy is then implemented in the hope of improving students' academic grades in preparation for continuing to the next level.

The background to the implementation of five school days is the assumption that weekend breaks are believed to be able to intensify the communication of students with their families at home. Every parent must pay attention to the quality of meetings with their children outside school hours so that communication between family members can go well. In creating the attitudes, personality, and character of children, the closeness of relationships, affection, guidance and excellent education from parents is no less important than the education of children in school. It is time for all parents to have a proper concern for the educational needs of children. Not a few parents who only give up their children's education to school, after that at home children are given unlimited freedom, without getting the guidance and supervision needed in education. The role of parents, educators, families, and communities is very supportive of the success of learning.

The implementation of the five-day school policy is not only aimed at shaping the character of students but is also understood by Principals, Wakakurriculum, and 
State High School teachers in Semarang City so that they progressively implement this policy aimed at meeting the interests of teachers who have been short of teaching hours. With this, it is hoped that, through the addition of guarding hours in each school, the complaints that have been raised by educators can be resolved. With this five-day school policy, it is no longer a hassle to pursue teaching hours in various schools to fulfill the teaching hours. Implementation of the five-day school will have an impact on changes in working hours for teachers if previously teachers only had an obligation to teach 24 hours per week, currently, regarding existing regulations, teachers are required to meet 40 hours per week. Forty hours per week is not only counted from face-to-face teaching alone. Break time will also be calculated from the 40-hour section.

\section{Juridical Reasons for the Five-Day School Policy}

The juridical reasons for the five-day school policy are derived from laws and regulations relating to the administration of education such as: (1) Law Number 20 the of 2003 concerning the National Education System (2) Law Number 14 of 2005 about Teachers and Lecturers; (3) Law Number 5 of 2014 concerning State Civil Apparatus; (4) Government Regulation Number 74 of 2008 concerning Teachers; (5) Government Regulation Number 17 of 2010 concerning Management and Implementation of Education; (6) Government Regulation Number 53 of 2010 regarding Discipline of Civil Servants; and (7) Presidential Decree Number 68 of 1995 concerning Working Days in Government Institutions.

Article 4 of Law No.20 of 2003 also states that "Education is carried out in a democratic and just and non-discriminatory manner by upholding human rights, religious values, cultural values, and national diversity." The 1945 Constitution of the Republic of Indonesia and Law No. 20 of 2003 concerning National Education System is very basic in providing philosophical foundation and various basic principles in the development of education, such as the philosophy of national education based on the philosophy of Pancasila, the education paradigm and complete human empowerment, the lifelong learning paradigm centered on learners, the education paradigm for allinclusive, and educational standards for development, development and/or sustainable development.

RI Law No. 14 of 2005 concerning Teachers and Lecturers is one of the juridical foundations regarding teachers as professionals must meet teaching hours set by Permendikbud No. 23 of 2017 concerning School Days. In it, among others, determine the position, function and purpose of the teacher; the principle of professionalism; teacher qualifications, competencies and certifications; teacher rights and obligations; teacher appointment, placement and dismissal; teacher development and development; appreciation and protection of teachers; leave; professional organizations and teacher code of ethics.

Political law in the view of Mahfud MD (2014: 1) is formulated that legal politics as legal policy or (policy) official about the law that will be enacted, both by making new laws or by replacing old laws, in order to achieve the goals of the country as 
stated in the Enforcement 1945 Constitution. In this case, the five-day school policy is the official policy of the government, as outlined in Permendikbud Number 23 of 2017.

The formulation of legal politics Mahfud MD (2014: 1) above has a substantive formulation of legal politics that legal politics is a fundamental policy that determines the direction, form, and content of the law to be formed. Based on the understanding as described above, it can be understood that the Indonesian government and legal politics can be distinguished from a number of significant historical events related to the educational system policy and legal politics as well as changes in the education curriculum which are often understood along with and in tune with the developments and modifications of the times.

Political Law in the field of education (Education Legal Policy) covers the making of education law and the implementation of education law in Permendikbud Number 23 of 2017 concerning School Days. The five-day legal provisions in one week are made to implement the national goals listed in the opening of the 1945 Constitution which is to educate the nation's life. The 1945 Constitution, Article 31 paragraph (2), states that: the government strives and organizes a national education system, which enhances faith and piety and noble character to educate the nation's life regulated by law.

After the rules followed the rules in the 1945 Constitution in the Regulation of the Minister of Education and Culture No. 23 of 2017 concerning School Day which is the result of political consensus, in the five-day school policy in Permendikbud Regulation No. 23 of 2017 concerning School Days there is a political influence on education as revealed by Mahfud MD (1999: 11-12) In the study of the relationship between politics and law there are three underlying assumptions, namely law determinants of politics, politics of determinants of law, and politics and law are intertwined in interdependent relationships.

Politics is a determinant of the law of the five-day school policy as regulated in Permendikbud Number 23 of 2017 concerning School Days. This is in line with the theory of Mahfud MD (1999: 11-12) that "political determinants of law, in the sense that in reality, both the normative product and the implementation of law enforcement, are strongly influenced and become a variable on politics." The link between education and politics is very close and even always related so that with these circumstances, it makes the country's politics play an essential role in determining the direction of the development of education in Indonesia. In this case, the researchers argue that education is one of the efforts or means to preserve state power. Michael W. Apple explained that the political culture of a country is channeled through its educational institutions so that education directed political will or power system in a society.

Education and politics, informal schools with a five-day school policy as stipulated in Permendikbud No. 23 of 2017, has been established from the center even though now it has implemented educational autonomy. This is what underlies the thinking of researchers that politics influences or determinants of government policies to be applied in schools. This is also because the political system prevailing in Indonesia is always associated with policies made by the state including policies in the field of education. The link lies in (1) policy formulation; (2) the process of 
legitimacy; (3) the delivery process to the public; (4) the communication process; (5) the implementation process, and (6) the evaluation process (Purwanto, 2008: 3).

The making of Permendikbud No. 23 of 2017 in which there is a significant role of political politics and can include three things, namely first, is a state policy (official line) about the law that will be enacted or not enforced in the context of achieving state goals especially in the field of character education. Second, the political, economic, social, cultural background of the birth of legal products; third, law enforcement in field reality (Mahfud, 2009: 4). In this case, legal politics is a public policy of organizing the state that sets the direction of the goals and intentions to be achieved in a development field and is contained in the state's constitution and regulations, including in the Minister of Education Regulation No. 23 of 2017 concerning School Days.

Government policies in the field of education, in particular by implementing five days of schooling and politics, are very carefully even always related so that with these conditions, we can know that state politics play a significant role in determining the direction of educational development in a country. It is no exaggeration if many experts think that education is one of the efforts or means to preserve state power. Michael W. Apple in Tilaar (2003: 145) explains that the political culture of a country is channeled through its educational institutions so that in education directed political will or power system in a society.

The results of this study found that political determinants of law or five-day school policies are in line with Purwanto's research findings (2008: 10) that education is not a political tool, but politics is education and vice versa education cannot choose an education that is not following state needs. (voting, in this case, are policies that are appropriate or beneficial to individual citizens). On the other hand, the rule of law can be achieved through education, political education. The goal of the Indonesian state is to realize the people with a political system that is sovereign of the people. Diverse Indonesian society is the formation of educated people who already have a broad view (mostly in the city) formed by education and opportunity. Education lies in the political order, while centralized/centralized power gives rise to group domination whose impact is impoverishment as a result of control rather than on the broader community so that rulers become unreachable by law.

Based on the analysis of Permendikbud Regulation No. 23 of 2017 concerning School Days it is known that the formation of regulations on the 5 day school policy can basically be seen from the system theory proposed by Harry C. Bredemeier developed by Talcott Parsons (Harry C. Bredemeier, 1962) namely "Law as an Integrative Mechanism" that in principle the lawmaking process takes place in four major stages, namely the initiation stage, the socio-political stage and the juridical stage, and the stage of dissemination or dissemination (Rodiyah, 2012: 148).

First, the initiation stage is the stage that marks the birth or emergence of an idea in society. Second, the activities that took place at the socio-political stage began with processing, discussing, criticizing, defending the initial ideas originating from the community through the exchange of opinions between various groups and forces in society. Third, namely, the juridical stage is the final stage where the idea is elaborated or further formulated more technically into legal provisions, including 
establishing legal sanctions. The fourth stage is the stage of dissemination or dissemination, a scene of the socialization of a legal product.

Regulation of the Minister of Education and Culture No. 23 of 2017 concerning School Days has three substances in it, namely the strengthening of character education at the high school level, provisions on school days and hours, and the implementation of school day provisions. The substance of the Regulation of the Minister of Education and Culture No. 23 of 2017 concerning School Day has close links with the typology of the society in which the law is made and enforced. In this case, Chambliss and Seidman make legal distinctions according to "a consensus-based typology of society" with "a conflict-based typology of society." (Rodiyah, 2012: 148). According to Robert B. Seidman and William J. Chambliss, that the process of the operation of law is mostly determined by four main components, namely law-making institutions (law), law enforcement bureaucracy, role holders, and the influence of personal and social forces. The first three components (law-making institutions, law enforcement bureaucracy, and role holders) play a role in the legal corridor, while personal and social power are "non-legal" components.

The issuance of the five-day school policy has the goal, as expressed by Rodiyah (2017: 93), that the implementation of a policy in the field of education aims to achieve substantive justice, namely real justice. The primary consideration of substantial justice is no longer looking for formal aspects (state law) and material (material law) but the nature of the legal issues, namely the exclusion of morality, ethics, and religious considerations. The formation of educational policies in an educational institution can occur through the logic of the theory of the operation of law in society (Chambliss and Seidman).

The Five Day School Policy is an example of orthodox government policy. In the view of Noel F. McGinn (2008: 277), it is said that educational policies decided by stakeholders should promote social cohesion. Instead of creating chaos or even division of social cohesion between schools, teachers and education practitioners. This is because the main objective of the national education strategy is to support the development of human resources through education.

From the explanation above, we can conclude that the Minister of Education and Culture Regulation No. 23 of 2017 concerning School Day is made and launched by political actors as policymakers only for the sake of realizing the ideals in the vision and achievements. That is, this policy includes orthodox character policies in which community participation is not involved in the formulation of the Five Day School policy, and the orientation of its interests is more oriented towards achieving vision and achievement in strengthening character education alone without looking at the benefits and welfare of the community and stakeholders associated with the education policy. The impact of this conservative policy is the amount of rejection that has occurred from observers of national education and several Islamic Community Organizations because it is felt that it will destroy traditional education such as madrasa diniyah, madrasa Qur'an, natural schools and private tutoring. 


\section{IMPLEMENTATION OF PERMENDIKBUD NUMBER $23 \mathrm{OF}$ 2017 CONCERNING SCHOOL DAYS IN SEMARANG CITY}

The implementation of Permendikbud No. 23 of 2017 concerning School Days in this study was analyzed with the implementation theory of Van Meter and Van Horn (Wahab, 2004: 79) which includes standards and policy objectives; policy sources; characteristics / characteristics or nature of the implementing agency / agency; communication between organizations related to implementation activities; the attitude of the implementers; economic, social and political environment. In this study only focused on four aspects, namely communication, disposition, human resources and bureaucracy (SOP).

\section{A. Communication}

At the beginning of the implementation of Permendikbud No. 23 of 2017 aimed at improving the quality of education in Central Java, exceptionally high school education. However, it must go through systematic stages, starting from proper planning, then being implemented, and has been well followed. This means that all state high schools in the city of Semarang are ready in terms of infrastructure and facilities, for the duration of their study, it has been communicated by involving psychologists and education experts, so students are not victims because of the relatively long learning period, which is 7 am to $7 \mathrm{pm} 5 \mathrm{pm}$.

Communication-related to the five-day school policy is carried out through socialization activities. In this case, socialization is the first step that must be taken to provide the direction needed so that targets in this policy can understand the concepts and guidelines regarding Character Strengthening Education. The socialization is carried out by inviting representatives from the school to provide a basic understanding of the importance of applying the five-day school policy as a reinforcement of character education to students. It is hoped that after participating in several series of socialization programs, school representatives will be able to benefit and be able to implement the five-day school policy independently in a gradual process.

State High Schools in Semarang in implementing Permendikbud Number 23 of 2017 have first communicated with parents and students. In this socialization effort, the students and parents have agreed and fully supported the school's policy to implement five school days.

\section{B. Disposition}

Disposition is the willingness, desire, and tendency of the actors to carry out the policy seriously so that what is the goal of the policy can be realized. Disposition is the character or characteristics possessed by the implementor. Disposition determines the success of policy implementation. If the implementor has a pleasant disposition, then he will be able to run the policy as well as what is desired by policymakers. 
Disposition holds an essential role in the success of policy implementation. This is because, in carrying out their duties, one must understand and have a good view related to the policy (Budi Winarno, 2007: 174).

Implementing an effective five-day school policy at the Semarang City Public High School requires that program standards and objectives need to be understood by the people responsible for achieving these goals. Therefore, clarity of standards and objectives, accuracy of policy communication for implementers, and consistency (or uniformity) must be communicated through various information. Measures and purposes cannot be carried out unless the policy is stated with sufficient clarity so that the implementer can know what is expected from the policy. Communication within and between organizations is a complex and challenging process.

State High Schools in Semarang City have implemented a five-day school policy, where teachers have a positive response because many teachers in Semarang City High Schools want Saturday as a holiday so they can have time to rest, do other activities, or build the intensity of relationships in the family after parents. Much work at home is carried out by teachers who incidentally as a housewife can be completed but often delayed, because the time allocation that has been available for household affairs is only on Sundays.

Disposition to the implementation of Permendikbud Number 23 of 2017 concerning School Days on the four State High Schools in the City of Semarang is a commitment from the school to implement a five-day school policy. Commitment is evidenced by looking at the reasons for School Principals, Wakakurriculum, and teachers to be able to implement five-day school implementation, goals/changes to be achieved, and changes that have been produced by schools by implementing a five-day school policy. The five-day school policy in the four-state high schools in Semarang City has a goal, which is to support central government policies related to strengthening character education for students through schools, parents and the community.

The policy change from six school days to five school days was positively responded to by SMA Negeri 14,5,6 and 11 Semarang. This is because the policy is prepared to produce a generation that is ready to face the future by reinforcing character. The existence of this policy change teachers welcomed with enthusiasm such as participating in all activities organized by the government related to the achievement of the implementation of Permendikbud No. 23 of 2017. Teacher readiness is essential in implementing Permendikbud No. 23 of 2017 because teachers as a determinant of success to create environmental conditions schools that support until the afternoon are expected to prepare and open themselves to various possibilities for change.

The concrete manifestation of the implementation of the five-day school policy at the State High School in Semarang City is the implementation of school rules and sanctions in stages. School regulations in the form of school rules are a collection of regulations made in writing and binding within the school environment. In this case, there is a period from morning to evening students, and teachers are at school so each school sets school rules with the primary aim so that all students and teachers in the 
school know the duties, rights, and obligations and carry out well so that school activities can run smoothly.

School regulations that have been made have also been established with sanctions or penalties for those who break them in stages, from mild, moderate to severe sanctions. The punishment handed down as a last resort considered for student development. Thus, the event of a student's soul is not and should not be harmed. In this case the provisions in the school rules are made with the aim that is that students know their duties, rights, and obligations, know the things that are allowed and increased creativity and avoid problems that can complicate themselves, students understand and carry out well all activities that are has been programmed by both intra-curricular and extracurricular schools.

\section{Human Resources}

Policy sources are an essential factor in implementing five-day school policies in Permendikbud No. 23 of 2017 to be effective. This is as Subarsono's opinion (2013: 91) that without resources, policies are just a paper that becomes a document. These resources include human resources, financial resources, and infrastructure resources.

The five-day school policy is an implementation of the Character Building Strengthening (PPK) program. The program focuses on five central values, namely religious, nationalist, cooperation, independence, and integrity. School policy eight hours a day or five days a week does not mean that students will study for eight hours in class. In this case, parents and the public are socialized not to imagine this policy keeps students in class all day. This policy wants to encourage students to carry out activities that foster character and 2lst-century skills. All high school teachers in Semarang City have also received instructions to avoid 'lecturing' activities in the classroom and replacing them with positive actions. These activities are not only carried out in the school environment but also in public places, which means a comparison of the portion of the learning process, which is 70 percent character building and 30 percent knowledge.

Human resources are teachers who are as educators, mentors, and mediators in the learning process. The teacher is the spearhead of the success of a curriculum change. Then the teacher must have adequate and mature readiness, starting from the availability in terms of qualifications, competencies, and also being ready in terms of the common understanding and paradigm (mindset) of the new curriculum. Teachers on state high schools in the city of Semarang are teachers who already have adequate quality and quantity from a minimum level of tertiary education, professional, and competency in their field.

The human resource factor of the school in terms of quantity of human resources in Semarang City State High School is sufficient to implement the five-day school policy in Permendikbud No. 23 of 2017. The quality of school teachers and education personnel also have good quality and competence so that it can support the implementation of a five-day policy school in Permendikbud Number 23 of 2017.

Policy sources other than human resources also come from the budget or infrastructure of state high schools in Semarang City support the implementation of 
the five-day school policy. In this case, due to an increased teacher working hours so that the impact on the increased budget. All state high schools in Semarang City do not have problems with financial resources to implement the five-day work policy. This is as Mazmanian and Sabatier's opinion as quoted by (Subarsono, 2005: 97), which says that financial resources are crucial factors that support the policy. Financial resources become very important in determining the success or failure of the implementation of the five-day school policy, and even the five-day school policy requires a massive budget to produce quality programs or policies as well.

\section{Bureaucracy}

Based on the results of this study, it can be concluded that the bureaucracy of the State High Schools in the City of Semarang in implementing the five-day school policy is good enough. Seen from the aspect of SOP, it has been explained to the teacher that there are additional assignments, but there is no written SOP yet. The absence of a written SOP is not an obstacle for both teachers and students in implementing Permendikbud Number 23 of 2017.

The implementation of the five-day school policy for state high schools in the city of Semarang is supported by the characteristics of the policy implementing agency, namely the Semarang City State High Schools. The Semarang City Government through the Semarang City Education Office fully supports the Character Strengthening Education policy from the center which is then used as a guideline. With this guideline, schools will be given technical instructions and implementation instructions, then support the facilities and infrastructure needed to support the policy and not forget the Government also monitors and evaluates the implementation of the policy so that it is in line with shared expectations.

Implementation of the five-day school policy in Permendikbud Number 23 of 2017 concerning School Days requires executors as executors who can come from agencies or institutions in government. In the five-day school policy, the central government mandates the Head of the Ministry of Education and Culture to provide direction to the Education Office in each region in Indonesia including the Semarang City Education Office that there is a need for training and seminars to be continued to schools that will be implementing a five-day school policy.

These results indicate that the structure of the bureaucracy is one of the essential factors in the implementation of the advertisement policy. There are two main characteristics of the bureaucracy, according to Edward, namely the working procedures of fixed size or often referred to as Standard Operating Procedures (SOP) and fragmentation (Winarno, 2014: 206). A good SOP is a framework that contains a clear, systematic, uncomplicated and easily understood by anyone because it will be a reference in the work of the implementor. Expectations with the existence of SOPs, policy support resources can carry out their duties under the standards set out in the SOP so that it can lead to effectiveness and efficiency of performance while implementing organizational structures as far as possible avoid things that are complicated, long and complex. 
The bureaucratic structure contained in the implementation of Permendikbud Number 23 of 2017 can be seen from the aspects of SOP and fragmentation aspects, wherein the SOP aspects the application is regulated by each school based on Permendikbud Number 23 of 2017 and the Circular of the Governor of Central Java as a reference and implementation guide for the teacher. In the aspect of fragmentation, state high schools in the city of Semarang have a bureaucratic structure to facilitate the distribution of tasks. Public High Schools in Semarang City have a clear bureaucratic structure and have followed the correct SOP from the school. Based on the results of the interview, it can be seen that aspects of the bureaucratic structure are included in the supporting factors for the implementation of Permendikbud Number 23 of 2017 concerning School Days.

\section{CONCLUSION}

Based on the results of research and discussion, it can be concluded that the substance of Permendikbud Number 23 of 2017 concerning School Days is the strengthening of character education at the high school level, the provisions on school days and hours and the implementation of school day provisions. The substance of the enhancement of character education is the basis for consideration in setting five-day school policies, the material of school days and hours is intended to regulate the use of school hours for teachers, education personnel and students while the substance of the implementation of school days regulates the implementation of the five-day school policy in stages according to with school readiness. The philosophical reasons for the five-day school policy are sourced from Pancasila and the opening of the 1945 Constitution to strengthen the character or character which is the spirit of the national spirit. The vision to become a nation that is characterized by declaring nation and character building as the nation's philosophy contained in the 1945 Constitution and Pancasila. Therefore Pancasila and the opening of the 1945 Constitution became a juridical basis in the issuance of Permendikbud Number 23 of 2017 concerning School Days. The sociological reasons for the five-day school policy are sourced from community phenomena including parents' interest in sending their children to fiveday school due to the increasing number of mothers working outside the home, increasing influence of television / social media and the association of students outside the home that is not controlled so with establish five school days so the school can maximize its role in shaping the character of students while in the school environment and intensifying communication between students and families at home over the weekend. The juridical reason for the five-day school policy is sourced from laws and regulations. The stipulation of five school days is based on the fact that every child has the right to education, the implementation of the educational function in the formation of student character and the administration of learning that is democratic and fair and non-discriminatory, as well as fulfilling the obligation to total teaching hours for teachers as employees of the state civil apparatus.

The implementation of Permendikbud No. 23 of 2017 concerning School Days by the State High Schools in the City of Semarang is supported by four aspects, namely 
(a) the communication aspect, which is the communication going smoothly between the Education Office and the school and the school with parents communicating well related to policy implementation five school days as an effort to strengthen character education for students; (b) the disposition aspect is the commitment of the school to implement the five-day school policy. Commitment is evidenced by looking at the reasons for School Principals, Wakakurriculum, and teachers to be able to implement five-day school implementation, goals/changes to be achieved, and changes that have been achieved by schools by implementing a five-day school policy. (c) The aspect of human resources, namely the readiness of human resources both in terms of the quantity and quality of education and education personnel to obtain additional assignments or burdens as student companions. (d) bureaucratic aspects, namely the existence of SOPs and the division of tasks and work for teachers that have been determined by the school so that they serve as guidelines in carrying out the activities of teachers and students while in school.

Suggestions that researchers can submit based on the research results obtained are (1) it is recommended to the Government to be able to conduct a public test on the Principal and Deputy Principal, School Committee and Teachers in order to be able to equate the perception of the purpose of making Minister of Education Regulation No. 23 of 2017 concerning School Days; (2) Principals should increase the intensity of socialization activities to the community related to the implementation of the five-day school policy to increase the understanding of counter-community issues related to Permendikbud No. 23 of 2017 concerning School Days. (3) State high school teachers in Semarang should not only position themselves as teachers but also be friends with students and become parents of both students at school so that efforts to strengthen character education for students can be more easily implemented.

\section{REFERENCES}

Apriyani et.al. (2018). Dari Full Day School ke Kebijakan Enam Hari Sekolah: Rasionalisasi Praktik Dan Evaluasi Pembelajaran Pasca Full Day School di SMA

Negeri 1 Kedungreja Kabupaten Cilacap. SOSIETAS, 8(1), 532-542. DOI: https://doi.org/10.17509/sosietas.v8i2.14740

Ashshofa, B. (2007). Metode Penelitian Hukum. Jakarta: Rineka Cipta

Hidayah, N. (2017). Kesiapan Sekolah dalam Implementasi Program Full Day School

(FDS) SD Muhammadiyah Di Kota Yogyakarta. Jurnal JPSD, 4(1), 38-46. DOI: http://dx.doi.org/10.12928/jpsd.v4i2.9609

Mahfud MD, M. (1999). Pergulatan Politik dan Hukum di Indonesia. Yogyakarta: Gama Media.

Mahfud MD, M. (2014). Politik Hukum di Indonesia. Jakarta: Rajawali Press.

Moleong, L.J. (2010). Metodologi Penelitian Kualitatif. Bandung: Remaja Rosdakarya.

Purwanto, N.A. (2008). Pengaruh Politik dalam Bidang Pendidikan. Jurnal Manajemen

Pendidikan, 4(2), 1-14. 
Rahem, Z. (2017). Dampak Sosial Pemberlakuan Full Day School (Menimbang Mafsadat-Maslahat Permendikbud 23/2017 Dan Perpres 87/2017). Jurnal Pendidikan Agama Islam, 3(1), 1-12.

Republic of Indonesia. (2010). Government Regulation Number 17 of 2010 concerning Management and Organization of Education (Peraturan Pemerintah Republik Indonesia Nomor 17 Tahun 2010 Tentang Pengelolaan dan Penyelenggaraan Pendidikan)

Republic of Indonesia. (2017a). Minister of Education and Culture Regulation

Number 23 of 2017 concerning School Day (Peraturan Menteri Pendidikan dan Kebudayaan Nomor 23 Tahun 2017 tentang Hari Sekolah)

Republic of Indonesia. (2017b) Presidential Regulation Number 87 of 2017 concerning Strengthening Character Education (Peraturan Presiden Nomor 87 Tahun 2017 tentang Penguatan Pendidikan Karakter)

Rodiyah. (2012). Aspek Demokrasi Pembentukan Peraturan Daerah dalam Perspektif Socio-Legal. Masalah Masalah Hukum, 41(1), 144-152.

Rodiyah. (2017). Philosophy of Progressive Law on Establishment of Laws and Regulations in the Context of Substantive Justice: an Indonesian Experience. International Journal of Business, Economics and Law, 13(4), 124-129.

Sari, P.R. (2017). Implementasi Full Day School (Sekolah Sehari Penuh) Sebagai Best Practice (Latihan Terbaik) Dalam Pendidikan Karakter di SMA Negeri 1 Sragen. Jurnal Penelitian, 3(1), 1-16.

Subarsono, A.G. (2013). Analisi Kebijakan Publik Konsep, Teori, dan Aplikasi. Yogyakarta: Pustaka Pelajar.

Sugiyono. (2015). Metode Penelitian Kuantitatif Kualitatif e RND. Bandung: Alfabeta Tilaar, H.A.R. (2003). Kekuasaan dan Pendidikan. Magelang: Indonesia Tera.

Wahab, S.A. (2004). Analisis Kebijaksanaan Dari Formulasi Ke Implementasi Kebijaksanaan Negara. Jakarta: Bumi Aksara.

Winarno, B. (2007). Teori dan Proses Kebijakan Publik. Yogyakarta: Media Pressindo. 